Original Research Paper

\title{
Influence of Starter Cultures' Type on the Microbiological, Rheological and Sensory Properties of Ayran Samples from Goat's Milk
}

\author{
Alma Aytkozhaevna Shunekeyeva \\ Department of Engineering Technologies and Transport, Shokan Ualikhanov Kokshetau University, Kokshetau, Kazakhstan
}

Article history

Received: 15-02-2021

Revised: 10-03-2021

Accepted: 19-03-2021

Email: a.shunekeyeva@kgu.kz

\begin{abstract}
Dairy products are one of the most widely-investigated food products. However, reducing cost while improving nutritional value and flavour is a classic problem in milk production. Besides, consumers have increased demand for natural foods and beverages with high nutritional value, health and rich taste. All of this has spawned a growing academic interest in using different types of milk to replace raw cow's milk in recent years. In this research, drinkable fermented milk products from goat's milk with different starters were studied. The aim of this study was to describe and compare Fatty Acid (FA) profiles of ayran from goat milk produced by Saanen breeds. The microbiological, chemical (pH, lactic acid, total solids, protein), rheological and sensory properties of ayran samples were investigated during a 10-day storage period. This study found that both samples (Micromilk and Sacco) have little difference in the basic content and chemical composition of selected physical characteristics according to the instrumental and organoleptic evaluation results. However, although the first starter culture (Micromilk) sample had the highest overall evaluation score, the second sample (Sacco) had a tighter clot and shorter fermentation duration. Also, it was found that during storage of the concentrations of lactic acid microorganisms in fermented beverages, the type of sourdough was insignificant. The shelf life of ayran is limited to 10 days at a temperature of $4 \pm 2^{\circ} \mathrm{C}$.
\end{abstract}

Keywords: Ayran, Bacteria, Fatty Acid, Method, Milk, Storage

\section{Introduction}

A survey conducted by (Altay et al., 2013) reveals the worldwide popularity of fermented foods and their important role in the human diet for their health benefits. A possible explanation for this might be that fermentation increases the bioavailability of minerals and the digestibility of proteins and carbohydrates and also improves the product's organoleptic qualities (Altay et al., 2013). In this context, traditional Kazakh fermented milk drinks have recently attracted researchers' attention due to their probiotic characteristics (Altay et al., 2013).

Ayran is a drinkable fermented milk product produced by the addition of Streptococcus thermophilus and Lactobacillus delbrueckii subsp. bulgaricus to standardized milk for fermentation (Altay et al., 2013). Ayran is widely consumed in Central Asia, Eastern Europe and the Middle East (Kabak and Dobson, 2011). The chemical composition of ayran depends on the type of milk used, fat removal efficiency and the dilution rate. Ayran is easily digestible and a highly valued drink with high vitamin and calcium content (Altay et al., 2013).

Industrial production of ayran can be carried out by two different methods. In Turkey, it can be produced either by adding water to yogurt or the addition of water to milk first and then fermentation of diluted milk (Altay et al., 2013). In Kazakhstan, ayran is usually obtained by different types of raw-milk without adding salt or other additives, resulting in a drink thicker than Turkish ayran.

Caprine milk is characterised by lower heat resistance and high thermal methods are less suitable for processing goat milk (Barłowska et al., 2011). Serum separation/solid particle sedimentation, acidity development and low viscosity affect consumer acceptance in terms of mouthfeel and appearance and are related to quality characteristics during manufacturing, transportation and storage (Altay et al., 2013). 
Goat's milk with increased content of bioactive components constituted a valuable raw material for the production of ayran based on the process of lactic milk fermentation. The beneficial health properties of ayran are linked to the fatty acid profile of goat milk.

The starter cultures with probiotic and antimicrobial properties also enhance the functional properties of traditional foods (Altay et al., 2013). The generalisability of much-published research on this issue is problematic. A considerable amount of literature has been published on well-known lactic acid microorganisms. Overall, these studies suggest the efficacy of fermented milk drinks.

There remain several aspects of using local milk raw materials in Kazakhstan about which relatively little is known. Therefore, the objective of this study was to evaluate the nutritional and fatty acid compositions of ayran samples with different starter cultures.

\section{Materials and Methods}

\section{Raw Materials}

Goat's milk was obtained from the breeding farm "Zerenda" (Akmola region, Kazhymukan village). The goat milk was obtained from the goats of the Saanen. The animals had a mean body weight of $56 \mathrm{~kg}$ and were aged 3 and 4 years (the second and third lactation). Milking was carried out mechanically.

For the control sample was used starter culture from "Barnaul biofactory" (Lactobacillus delbrukii subsp. bulgaricus, Streptococcus salivarius subsp. thermophilus). The cultures were used in this study for comparison: Micromilk (Micromilk KF 45: Streptococcus thermophilus, Lactobacillus bulgaricus) and Sacco (Lyofast MT 030/031 N: Lactococcus lactis subsp. Lactis, Lactococcus lactis subsp. Diacetilactis, Lactococcus lactis subsp. Biovar diacetilactis, Lactobacillus brevis, Leuconostoc). Direct starter cultures are produced by the Italian companies. They were purchased locally from the market in Almaty, Kazakhstan.

\section{Ayran Manufacture}

Raw whole goat's milk was pasteurized at $85^{\circ} \mathrm{C}$ and kept for $15 \mathrm{~s}$ in a plate pasteurizer and subsequently cooled to $+45^{\circ} \mathrm{C}$. The process of the fermentation of milk to be processed was initiated by the addition of a mixture of homo- and heterofermentative strains of lactic acid bacteria, thermophilic lactic acid bacteria:

- control: starter culture from "Barnaul biofactory" (Lactobacillus delbrukii subsp. bulgaricus, Streptococcus salivarius subsp. thermophilus)

- Sample 1: Micromilk (Micromilk KF 45: Streptococcus thermophilus, Lactobacillus bulgaricus)

- Sample 2: Sacco (Lyofast MT 030/031 N: Lactococcus lactis subsp. Lactis, Lactococcus lactis subsp.
Diacetilactis, Lactococcus lactis subsp. Biovar diacetilactis, Lactobacillus brevis, Leuconostoc)

All cultures were thus added to the milk at a level of $2 \%$. When a final $\mathrm{pH}$ of 4.40 was reached, incubation was terminated and the resulting ayran samples were packed in plastic cups which were stored in a refrigerator at $4 \pm 2{ }^{\circ} \mathrm{C}$. Samples were taken and examined as described below after storage periods of 1,5 and 10 days. The experiment was based on three replicate cycles (Yilmaz et al., 2015). The frequency and choice of research methods in the described experiment allowed for full characterization of the initial material, analysis of the acidification dynamics and assessment of the quality of the resulting ayran.

\section{Physical and Chemical Analyses}

According to the state standard method GOST 362673 Milk and milk products, dry matter contents were determined. Methods for determination of moisture and dry substance (GOST 3626-73, 1974).

The $\mathrm{pH}$ of ayran samples was determined every hour at $20 \pm 1^{\circ} \mathrm{C}$ during fermentation and also storage at $4^{\circ} \mathrm{C}$. The $\mathrm{pH}$ of the samples was measured using a portable pH meter (Exspert-pH, Russia). Total solids, protein, fat, ash and titratable acidity were determined according to the methods described by the standard method by GOST 32892-2014 Milk and dairy products. Method of $\mathrm{pH}$ determination (GOST 32892-2014, 2016).

The acidity of the samples was measured in accordance with the requirements of state standard GOST 3624-92 Milk and milk products. Titrimetric methods of acidity (GOST 3624-92, 1994).

\section{Microbiological Analysis}

The samples of fermented milk drinks were measured in accordance with the requirements of GOST 9225-84 Milk and milk products. Methods of microbiological analysis (GOST 9225-84, 1986). Medium sucrose agar was used for the determination of viable counts of lactic acid bacteria count in ayran samples according to the state standard method GOST 10444.11-2013 Food products. Methods for determination of the lactic acid bacteria (GOST 10444.11-2013, 2015). Plates were incubated at $+45^{\circ} \mathrm{C}$ for $72 \mathrm{~h}$ under anaerobic conditions.

Meat-Peptone Agar (MPA) was used to enumerate the total aerobic mesophilic bacteria count in ayran samples according to the state standard method GOST 10444.15-94 Food products. Methods for determination of quantity of mesophilic aerobes and facultative anaerobes. Petri dishes were incubated aerobically at $+30^{\circ} \mathrm{C}$ for $72 \mathrm{~h}$ (GOST 10444.15-94, 1996).

Coliform bacteria and E. coli were determined using Kessler's medium according to the state standard GOST 31747-2012 Food products. Methods for detection and quantity determination of coliforms (GOST 31747- 
2012, 2013). Petri dishes were incubated aerobically at $+37^{\circ} \mathrm{C}$ for $48 \mathrm{~h}$.

Sabouraud agar was used to enumerate yeasts and moulds in ayran samples according to the state standard method GOST 10444.12-88 Food products. Method for determination of yeast and mould (GOST 10444.12-88, 1990). Plates were incubated aerobically at $+22^{\circ} \mathrm{C}$ for $72 \mathrm{~h}$.

Growth medium containing 6.5\% salt broth was used to enumerate yeasts and moulds in ayran samples according to the state standard method GOST 303472016 Milk and milk products. Methods for determination of Staphylococcus aureus (GOST 30347-2016, 2017). Plates were incubated aerobically at $+37^{\circ} \mathrm{C}$ for $24 \mathrm{~h}$.

\section{Sensory Analysis}

According to the state standard method ST RK 17322007 Milk and milk products, Fermented milk samples were organoleptically examined. Methods of sensory analysis (ST RK 1732-2007, 2007). Sensory characteristics of ayran samples were evaluate by a panel of ten experts from the laboratory of Food Products department of Almaty Technological University using a point scale.

\section{Viscosity}

Contingent viscosity measurements were taken at $20^{\circ} \mathrm{C}$ with a simple method: By-product leaking time from a pipette $(100 \mathrm{~mL})$ with outlet diameter $(5 \mathrm{~mm})$. The time of the clot leaking (at the end of fermentation) should be at least $20 \mathrm{sec}$. The average value of 5 measurements was taken.

\section{Structural and Mechanical Properties}

The rheological properties of samples were measured in glass cups with an indenter, which compressed the coagulum to the depth of $15 \mathrm{~mm}$, at compression rate of $10 \mathrm{~mm} / \mathrm{s}$. Each sample was measured in three replicate (Fig. 1). The method is based on measuring the maximum force at the moment of pushing the clot (ultimate strength) by an indenter moving at a constant speed. The device was invented by Siberian Scientific Research Institute (Russia).

The determination of the strength limit of a fermented milk clot reflects the structural and mechanical properties of the clot. The principle of operation of the device is based on the measurement of the strength limit of the sour milk clot when the indenter is immersed in the sample. The measurement results (converted to grams) are displayed on the monitor screen, as well as recorded in the computer memory (the program "Arduino"). Thus, this method of studying the process of fermentation of fermented milk drink is based on measuring the resistance that the indenter experiences when immersed in a sour-milk clot. A measuring device with a mechanical system and a control unit is connected by cable to a computer for data logging (Shunekeyeva et al., 2020).

\section{Fatty Acid Content}

Milk and ayran samples were analysed for fatty acid profiles using a gas chromatograph Crystallux 4000M (Research and Production Company «Meta-chrom», Russia). The chromatograph consists of an analytical unit, a station for controlling, monitoring and processing chromatographic information, which uses a personal computer and the "NetChrom" program operating in the Windows environment (http://www.ykanalytical.com/products/RPC/html/Crysta 14000M.html). Determination of the fatty acid composition of goat's milk and ayran samples was carried out according to the state standard method GOST 30418-96 Vegetable oils. Method for determination of fatty acid content. Observed peaks were identified by comparing retention times with appropriate fatty acid methyl ester standards (GOST 30418-96, 1998).

Prior to statistical verification of analytical results, fatty acids identified in raw milk and ayran samples were grouped in the following categories:

- $\quad$ Saturated Fatty Acids (SFA) (C10:0; C12:0; C14:0; C15:0; C16:0; C18:0)

- Monounsaturated Fatty Acids (MUFA) (C18:1n9c; C20:1)

- Polyunsaturated Fatty Acids (PUFA) (C18:2cn6t; C18:3n6Y; C20:4n6; C20:5n3)

- Conjugated Linoleic Acids (CLA) (C18:2cn6t; C18:3n6Y) (Yilmaz et al., 2015).

\section{Statistical Analysis}

Mathematical processing of the experiment results was performed using a statistical method based on the software package «Microsoft Excel» and Statistica (StatSoft, Russia) statistical software. Samples were analyzed twice on days 1, 5, 10 of storage analysis (Yilmaz et al., 2015).

Results were presented as the mean \pm standard deviation. Mean separation using was carried out for statistical analysis of the treatment and storage effect on the viable microorganisms and $\mathrm{pH}$ and antioxidant activity over the 10 day period of storage. Data was significant if the $p$ value was found to be $<0.05$.

\section{Results and Discussion}

\section{Compositional Analysis}

Ayran samples prepared by lactic fermentation from Saanen goats differed slightly in terms of the basic chemical composition (Table 1).

Further, independent of the time of storage, there were no differences between fermented beverages in the content of fat, protein, lactose and minerals. There was no increase found in the active acidity during the refrigerated storage of dairy drinks. 
The $\mathrm{pH}$ of the ayran samples after 10 days' storage was decreased (by 4\%) and it remained at this level until the end of the experiment. Titratable acidity of both ayran samples increased on average by $7 \%$ over 10 days.

\section{Microbiological Analysis}

The results of the specific microorganisms (Escherichia coli, Staphylococcus aureus and Salmonella, moulds and yeasts in the ayran samples showed that they were not detected. The results of the total number of mesophilic aerobic and facultative anaerobic microorganisms show that the lowest values were found for the ayran sample S1 (incubated with starter culture Micromilk). The changes of the total number of viable lactic acid bacteria for 10-day storage at a temperature of $2-6^{\circ} \mathrm{C}$ for ayran samples were investigated. It was found that during the storage concentrations of lactic acid microorganisms in the fermented beverages were insignificantly affected by the kind of starter culture. The change in the amount of lactic acid bacteria that occurs during the storage period in the ayran samples is due to the type of starter culture.

The reason for the growth rate of bacteria (mesophilic aerobic and facultative anaerobic) in control sample may also be that the starter culture has been inhibited at the moment of inoculation. The increase in lactic acid bacteria suggests that the starter culture (Micromilk) contained more resilient lactic acid bacteria. These results findings suggested that the low content of lactic acid bacteria in the control sample is due to a decrease in the effectiveness of the starter culture due to the need for preliminary short-term activation before introducing it into goat's milk.

As is clearly seen in Table 2, the duration of production of fermented milk bacteria during the storage period was longer in sample 1, while sample 2 showed a decrease.

The increased bacterial contamination of the product was detected in sample 2. It is possible that because the number of lactic acid bacteria has decreased in the same ayran sample. The numbers of lactic acid bacteria, total aerobic mesophilic bacteria are given in Table 2 .

\section{Sensory Analysis}

A lack of differences in the basic chemical composition and selected quality characteristics of both ayran samples was also noted during the sensory evaluation. It was found that the flavour and aroma descriptors, as well as ayran consistencies did not differ, irrespective of the storage time (Table 3).

Table 1: Basic composition and nutritive value of raw (goat milk) and ayran samples (mean values)

\begin{tabular}{lllll}
\hline Item & GM & S1 & S2 & C \\
\hline Fat $(\%)$ & $2.5 \pm 0.05$ & $2.5 \pm 0.05$ & $2.5 \pm 0.05$ & $2.5 \pm 0.05$ \\
Protein $(\%)$ & $3.27 \pm 0.02$ & $3.2 \pm 0.02$ & $3.2 \pm 0.02$ & $3.23 \pm 0.02$ \\
Lactose $(\%)$ & $4.82 \pm 0.1$ & $4.7 \pm 0.18$ & $3.95 \pm 0.15$ & $4.2 \pm 0.2$ \\
Minerals $(\%)$ & $0.81 \pm 0.15$ & $0.68 \pm 0.15$ & $0.62 \pm 0.15$ & $0.65 \pm 0.15$ \\
Energy value $(\mathrm{kcal} / \mathrm{kJ})$ & $59 / 247$ & $56 / 234$ & $51 / 213$ & $52 / 218$ \\
Titratable acidity $\left({ }^{\circ} \mathrm{T}\right)$ & $18 \pm 1$ & $110 \pm 1$ & $113 \pm 2$ & $115 \pm 2$ \\
pH & $6.58 \pm 0.02$ & $4.6 \pm 0.02$ & $4.64 \pm 0.02$ & $4.56 \pm 0.02$ \\
\hline
\end{tabular}

GM: Goat Milk. S1: Ayran sample produced using starter culture Micromilk. S2: Ayran sample produced using starter culture Sacco. C: Control produced using starter culture from "Barnaul biofactory"

Table 2: Results of microbiological analysis $(\mathrm{n}=3)$

\begin{tabular}{lllll}
\hline & & \multicolumn{2}{l}{ Storage period (days) } & \\
Microorganisms (CFU/ ml) & Cultures & 1 & 5 & 10 \\
\hline Lactic acid bacteria & Micromilk & $(4 \pm 0.04) \times 10^{7}$ & $(3 \pm 0.02) \times 10^{7}$ & $(1.2 \pm 0.06) \times 10^{7}$ \\
& Sacco & $(1 \pm 0.02) \times 10^{7}$ & $(6 \pm 0.05) \times 10^{6}$ & $(4.8 \pm 0.02) \times 10^{6}$ \\
& "Barnaul biofactory" & $(1.2 \pm 0.03) \times 10^{7}$ & $(3.5 \pm 0.07) \times 10^{7}$ & $(1 \pm 0.02) \times 10^{6}$ \\
Total mesophilic aerobic and & Micromilk & $(1 \pm 0.02) \times 10^{2}$ & $(2.3 \pm 0.05) \times 10^{3}$ & $(3.1 \pm 0.04) \times 10^{3}$ \\
facultative anaerobic microorganisms & Sacco & $(1 \pm 0.02) \times 10^{2}$ & $(3 \pm 0.04) \times 10^{3}$ & $(1 \pm 0.05) \times 10^{4}$ \\
& "Barnaul biofactory" & $(5 \pm 0.05) \times 10^{2}$ & $(1.5 \pm 0.04) \times 10^{3}$ & $(2.4 \pm 0.02) \times 10^{3}$ \\
\hline
\end{tabular}

CFU/ml: The number of bacteria per ml.

Table 3: Sensory characteristics of the ayran samples

\begin{tabular}{llll}
\hline Evaluated parameters & S1 & S2 & C \\
\hline Taste and odour & Clean sour milk taste and smell & Clean sour milk taste and smell & Clean Sour milk taste and smell \\
Consistency and appearance & Homogeneous, Thick, Viscous & Homogeneous, Thick, Viscous & Homogeneous, liquid, viscous \\
Colour & White & White & White \\
By 10 point rating scale & $9 \pm 0.03$ & $8 \pm 0.4$ & $7 \pm 0.12$ \\
\hline
\end{tabular}

S1: Ayran sample produced using starter culture Micromilk. S2: Ayran sample produced using starter culture Sacco. C: Control 


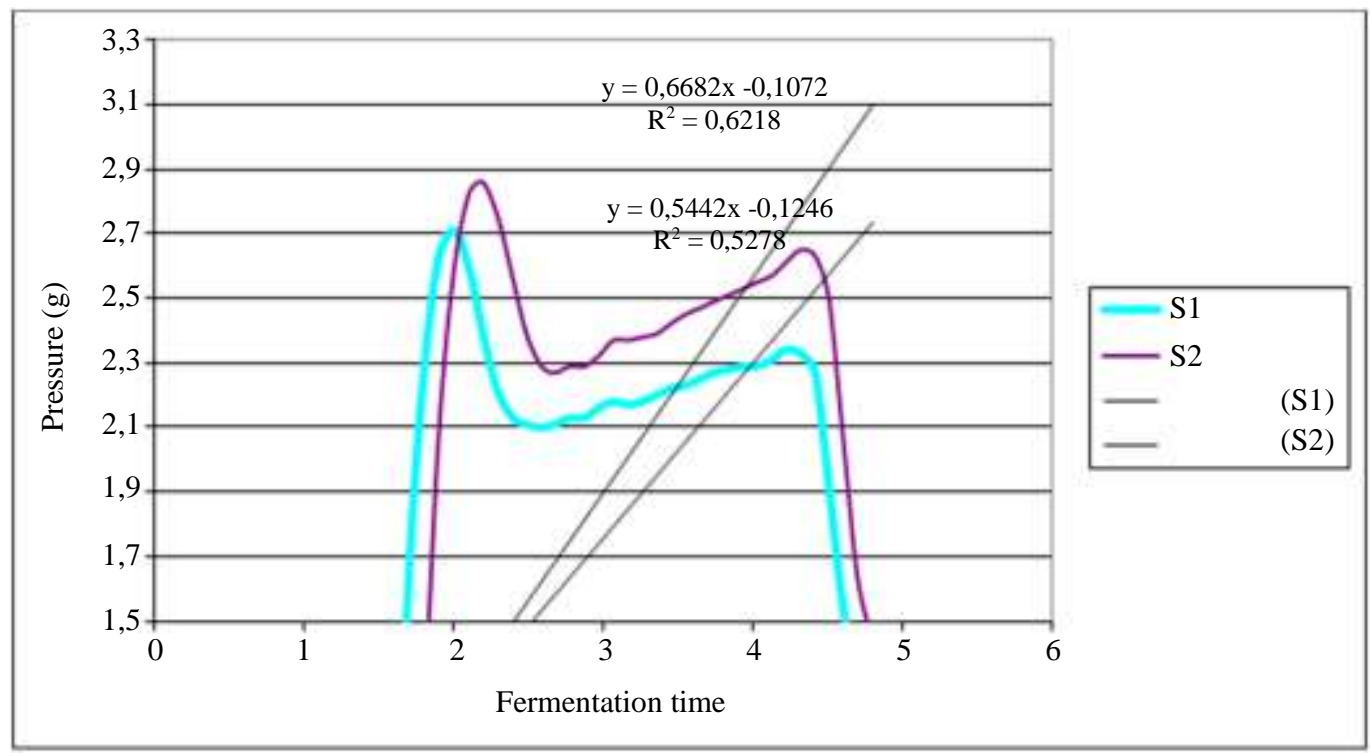

Fig. 1: The rheological properties of the ayran samples (S1, S2)

According to the sensory results, ayran produced from starter culture (Micromilk) had the highest overall evaluation score. Overall, the sensory characteristics of ayran samples were significantly affected by the incubation conditions. The type of starter culture is thought to be important in this process, which can also be the case in ayran (Yilmaz et al., 2015).

\section{Structural and Mechanical Properties}

According to results, ayran Sample (S2) had shorter fermentation time and firmer coagulum. Addition of exopolysaccharide producing cultures (Sacco) decreased whey separation and caused an increase in viscosity in ayran Sample (S2). As can be seen, the rheological properties of the ayran sample S1 decreased depending on the shear rate, indicating that ayran sample S1 showed shear thinning behavior (Yilmaz et al., 2015).

Furthermore, the linear regression equation of the ayran samples shows that the approximation confidence value (R2) is close to one, which allows an adequate search for optimal values of the studied processes' factors (are presented in Fig. 1). As can be seen, the rheological properties of the ayran Sample (S1) decreased depending on the shear rate, indicating that ayran Sample (S1) showed shear thinning behavior. Rheology properties of ayran samples were significantly affected by incubation temperature and time like previous observations in ayran (Yilmaz et al., 2015).

\section{Fatty Acid (FA) Content}

A number of recent studies are observed a relationship content of fatty acids between the lactation period and the feeding regime of goat's (Haile et al., 2016; Kiełczewska et al., 2020). The results obtained in this current study clearly demonstrate that there 12 types of FA in goat milk and ayran samples were detected.

Therefore Saturated Fatty Acids (SFA) were most prevalent for ayran samples from goat's milk analyzed. An analysis of the fatty acid profile of goat milk and ayran samples fat revealed a predominance of fatty acids C10:0, C14:0, C16:0, C18:0 and C18:1c9. For instance the sebacic acid (C10:0) levels observed in raw (goat milk) in the present study were somewhat higher than those previously reported in research (Yurchenko et al., 2018).

Caprine milk fat is a reward in short- and mediumchain fatty acids, particularly caprylic and decanoic (capric) acids like in previous studies (Kiełczewska et al., 2020). The fatty acid profile of raw milk and ayran samples is shown in Table 4 . The relative proportion of saturated, monounsaturated and polyunsaturated fatty acids of goat milk were coincides with the mean S1 practically. The predominant fatty acids in goat milk were oleic acid $(23.90 \%)$, palmitic acid $(28.16 \%)$, capric acid $(9.63 \%)$ and myristic acid $(9.27 \%)$. No significant correlation was found between fatty acids of goat milk and ayran Sample (S1). In turn, the ayran Sample (S2) had a lower content of unsaturated fatty acids, both mono- and polyenic $(\mathrm{p}<0.05)$.

The overall Atherogenic Index (AI) level in the current study was similar to earlier researches (Markiewicz-Kęszycka et al., 2013; Ayeb et al., 2015; Haile et al., 2016; Yurchenko et al., 2018). According to research has been found that DI18 represented the most appropriate result the product/substrate relationship for desaturase (Yurchenko et al., 2018). The other desaturases has unimportant values. Thermal treatment did not affect the fatty acid profile of caprine milk, excluding branched-chain fatty acids. 
Table 4: Fatty acid composition (\%) of raw milk and ayran samples

\begin{tabular}{lllll}
\hline Fatty acid & GM & S1 & S2 & C \\
\hline$C_{10: 0}$ & $9.63 \pm 2.04$ & $10.24 \pm 0.09$ & $10.91 \pm 0.19$ & $10.35 \pm 0.14$ \\
$\mathrm{C}_{12: 0}$ & $3.89 \pm 1.02$ & $3.93 \pm 0.12$ & $3.94 \pm 0.05$ & $3.57 \pm 0.02$ \\
$\mathrm{C}_{14: 0}$ & $9.27 \pm 1.45$ & $9.45 \pm 0.29$ & $7.98 \pm 0.54$ & $8.04 \pm 0.03$ \\
$\mathrm{C}_{15: 0}$ & $1.06 \pm 0.14$ & $1.05 \pm 0.28$ & $0.94 \pm 0.12$ & $0.82 \pm 0.34$ \\
$\mathrm{C}_{16: 0}$ & $28.16 \pm 0.25$ & $27.68 \pm 0.11$ & $26.57 \pm 0.08$ & $25.80 \pm 0.06$ \\
$\mathrm{C}_{18: 0}$ & $8.61 \pm 1.44$ & $8.96 \pm 0.06$ & $9.08 \pm 0.00$ & $8.86 \pm 0.00$ \\
$\mathrm{C}_{18: 1 \mathrm{n}-9 \mathrm{c}}$ & $23.90 \pm 0.02$ & $23.62 \pm 0.03$ & $23.05 \pm 0.02$ & $22.57 \pm 0.01$ \\
$\mathrm{C}_{20: 1}$ & $0.41 \pm 0.03$ & $0.32 \pm 0.01$ & $0.54 \pm 0.02$ & $0.23 \pm 0.05$ \\
$\mathrm{C}_{18: 2 \mathrm{cn} 6 \mathrm{t}}$ & $2.26 \pm 1.55$ & $0.34 \pm 0.05$ & $3.36 \pm 1.44$ & $2.51 \pm 0.01$ \\
$\mathrm{C}_{18: 3 \mathrm{n} 6 \mathrm{Y}}$ & $0.51 \pm 0.24$ & $0.46 \pm 0.01$ & $0.54 \pm 0.01$ & $0.43 \pm 0.00$ \\
$\mathrm{C}_{20: 4 n 6}$ & $2.21 \pm 0.31$ & $2.53 \pm 0.56$ & $0.42 \pm 0.05$ & $0.39 \pm 0.02$ \\
$\mathrm{C}_{20: 5 n 3}$ & $0.55 \pm 0.01$ & $0.51 \pm 0.00$ & $0.57 \pm 0.03$ & $0.52 \pm 0.02$ \\
SFA & $60.62 \pm 0.01$ & $61.31 \pm 0.03$ & $59.42 \pm 0.03$ & $57.44 \pm 0.02$ \\
MUFA $^{\mathrm{b}}$ & $24.31 \pm 0.02$ & $23.94 \pm 0.02$ & $24.77 \pm 0.01$ & $22.28 \pm 0.03$ \\
PUFA $^{\mathrm{c}}$ & $5.53 \pm 0.01$ & $3.84 \pm 0.11$ & $4.89 \pm 0.00$ & $3.85 \pm 0.02$ \\
CLA $^{\mathrm{d}}$ & $2.77 \pm 0.11$ & $0.8 \pm 0.02$ & $3.9 \pm 1.55$ & $2.94 \pm 0.00$ \\
$\omega-3^{\mathrm{e}}$ & $0.55 \pm 0.01$ & $0.51 \pm 0.00$ & $0.57 \pm 0.03$ & $0.52 \pm 0.02$ \\
$\omega-6^{\mathrm{f}}$ & $4.98 \pm 0.01$ & $3.33 \pm 0.03$ & $4.32 \pm 0.02$ & $3.33 \pm 0.02$ \\
Ratios of fatty acids $_{\omega-6: \omega-3}$ & $9.05 \pm 0.03$ & & & \\
AI & $2.31 \pm 0.02$ & $6.52 \pm 0.02$ & $7.57 \pm 0.02$ & $6.4 \pm 0.03$ \\
DI18 & $2.77 \pm 0.02$ & $2.49 \pm 0.01$ & $2.10 \pm 0.02$ & $2.35 \pm 0.01$ \\
\hline
\end{tabular}

${ }^{a}$ SFA - Saturated Fatty Acid (C10:0; C12:0; C14:0; C15:0; C16:0; C18:0).

${ }^{\mathrm{b}}$ MUFA - Monounsaturated Fatty Acid (C18:1n9c; C20:1).

${ }^{c}$ PUFA - Polyunsaturated Fatty Acid (C18:2cn6t; C18:3n6Y; C20:4n6; C20:5n3)

${ }^{\mathrm{d}}$ CLA - Conjugated Linoleic Acids (C18:2cn6t; C18:3n6Y)

e $\omega-3(\mathrm{C} 20: 5 \mathrm{n} 3)$

${ }^{\mathrm{f}} \omega-6(\mathrm{C} 18: 2 \mathrm{cn} 6 \mathrm{t} ; \mathrm{C} 18: 3 \mathrm{n} 6 \mathrm{Y} ; \mathrm{C} 20: 4 \mathrm{n} 6)$

$\mathrm{AI}=(\mathrm{C} 12: 0+4 \times \mathrm{C} 14: 0+\mathrm{C} 16: 0) /(\mathrm{MUFA}+\omega-6+\omega-3)$

DI18 = C18:1n-9c/C18:0

GM: Goat Milk. S1: Ayran sample produced using starter culture Micromilk. S2: Ayran sample produced using starter culture Sacco. C: Control. Mean values within each row (separate for milk and ayran samples) are different $(p<0.05)$.

However, with limited indicators of fatty acids caution must be applied, as the findings might be biased.

\section{Conclusion}

As the desired result, both ayran samples were successfully prepared with viable lactic acid bacteria counts up to an acceptable range and good antioxidant activity within 10 days. Both samples were obtained without adding supplements contributing to the texture, mouthfeel, taste perception and storage stability.

Though ayran from Saanen goats has higher proportions of C10:0, C16:0 and C18:1n-9c. There were no differences in the basic content and chemical composition of selected physical characteristics of ayran samples. Taking into account the results of the instrumental evaluation and organoleptic assessment, it was demonstrated that ayran samples did not differ in quality.

\section{Acknowledgement}

I would like to express my very great appreciation to Dr Alimardanova M.K. for her valuable and constructive suggestions during the planning and development of this research work.

\section{Ethics}

This article is original and contains unpublished material. The corresponding author confirms that the author has read and approved the manuscript and no ethical issues involved.

\section{References}

Altay, F., Karbancioglu-Güler, F., Daskaya-Dikmen, C., \& Heperkan, D. (2013). A review on traditional Turkish fermented non-alcoholic beverages: microbiota, fermentation process and quality characteristics. International Journal of Food Microbiology, 167(1), 44-56. https://doi.org/10.1016/j.ijfoodmicro.2013.06.016

Ayeb, N., Addis, M., Fiori, M., Khorchani, S., Atigui, M., \& Khorchani, T. (2015). Quality and fatty acid profile of the milk of indigenous goats subjected to different local diets in Tunisian arid lands. Journal of Animal Physiology and Animal Nutrition, $\quad 100, \quad 101-108$. https://doi.org/10.1111/jpn.12344 
Barłowska, J., Szwajkowska, M., Litwińczuk, Z., \& Król, J. (2011). Nutritional value and technological suitability of milk from various animal species used for dairy production. Comprehensive Reviews in Food Science and Food Safety, 10(6), 291-302. https://doi.org/10.1111/j.1541-4337.2011.00163.x

GOST 10444.11-2013 (2015). Food products. Methods for determination of the lactic acid bacteria. Standartinform. http://docs.cntd.ru/document/1200021090

GOST 10444.12-88 (1990). Food products. Method for determination of yeast and mould. Standartinform. http://docs.cntd.ru/document/1200021096

GOST 10444.15-94 (1996). Food products. Methods for determination of quantity of mesophilic aerobes and facultative anaerobes. Standartinform. http://docs.cntd.ru/document/gost-10444-15-94

GOST 30347-2016 (2017). Milk and milk products. Methods for determination of Staphylococcus aureus. Standartinform. http://docs.cntd.ru/document/1200142424

GOST 30418-96 (1998). Vegetable oils. Method for determination of fatty acid content. Standartinform. http://docs.cntd.ru/document/gost-30418-96

GOST 31747-2012 (2013). Food products. Methods for detection and quantity determination of coliforms. Standartinform. http://docs.cntd.ru/document/1200098583

GOST 32892-2014 (2016). Milk and dairy products. Method of $\mathrm{pH}$ determination. Standartinform. http://docs.cntd.ru/document/1200114186.

GOST 3624-92 (1994). Milk and milk products. Titrimetric methods of acidity. Standartinform. http://docs.cntd.ru/document/gost-3624-92

GOST 3626-73 (1974). Milk and milk products. Methods for determination of moisture and dry substance. Standartinform http://docs.cntd.ru/document/1200021586.

GOST 9225-84 (1986). Milk and milk products. Methods of microbiological analysis. Standartinform. http:/gostexpert.ru/data/files/922584/b7dc08d5a92aca74f7c2525ae05ed845.pdf.

Haile, A. B., Zhang, W., Wang, W., Yang, D., Yi, Y., \& Luo, J. (2016). Fatty acid synthase (FASN) gene polymorphism and early lactation milk fat composition in Xinong Saanen goats. Small Ruminant Research, 138, 1-11. https://doi.org/10.1016/j.smallrumres.2016.03.025
Kiełczewska, K., Jankowska, A., Dąbrowska, A., Wachowska, M., \& Ziajka, J. (2020). The effect of high pressure treatment on the dispersion of fat globules and the fatty acid profile of caprine milk. International Dairy Journal, 102, 104607. https://doi.org/10.1016/j.idairyj.2019.104607

Markiewicz-Kęszycka, M., Czyżak-Runowska, G., Lipińska, P., \& Wójtowski, J. (2013). Fatty acid profile of milk-a review. Bulletin of the Veterinary Institute in Pulawy, 57(2), 135-139. https://doi.org/10.2478/bvip-2013-0026

ST RK 1732-2007 (2007). Milk and milk products. Methods of sensory analysis. Standartinform. https://online.zakon.kz/Document/?doc_id=31070321

Yurchenko, S., Sats, A., Tatar, V., Kaart, T., Mootse, H., \& Jõudu, I. (2018). Fatty acid profile of milk from Saanen and Swedish Landrace goats. Food Chemistry, 254, 326-332. https://doi.org/10.1016/j.foodchem.2018.02.041

Kabak, B., \& Dobson, A. D. (2011). An introduction to the traditional fermented foods and beverages of Turkey. Critical Reviews in Food Science and Nutrition, 51(3), 248-260. https://doi.org/10.1080/10408390903569640

Yilmaz, M. T., Dertli, E., Toker, O. S., Tatlisu, N. B., Sagdic, O., \& Arici, M. (2015). Effect of in situ exopolysaccharide production on physicochemical, rheological, sensory and microstructural properties of the yogurt drink ayran: an optimization study based on fermentation kinetics. Journal of Dairy Science, 98(3), 1604-1624. https://doi.org/10.3168/jds.2014-8936

Shunekeyeva, A. A., Majorov, A. A., \& Alimardanova, M. K. (2020). Opredelenie strukturnomehanicheskih svojstv kislomolochnyh napitkov iz koz'ego moloka s napolniteljami [Determination of structural and mechanical properties of fermented milk drinks from goat's milk with fillers]. Nauchnyj zhurnal «Mehanika i tehnologii». N 3 (69), pp: 100-105. ISSN 2308-9865. 